\title{
Lower Risk of Death and Cardiovascular Events in Unselected Type 2 Diabetes Patients Initiated on GLP-1 Receptor Agonists and SGLT-2 Inhibitors in Two Large Italian Cohorts
}

Marta Baviera ( $\triangle$ marta.baviera@marionegri.it )

IRCSS: Istituto Di Ricerche Farmacologiche Mario Negri https://orcid.org/0000-0002-0264-151X

\section{Stefano Genovese}

Centro Cardiologico Monzino IRCCS: Centro Cardiologico Monzino Istituto di Ricovero e Cura a Carattere Scientifico

Vito Lepore

Coresearch Center for Outcomes Research and Clinical Epidemiology

Pierluca Colacioppo

IRCSS: Istituto Di Ricerche Farmacologiche Mario Negri

Fabio Robusto

Coresearch Center for Outcomes Research and Clinical Epidemiology

Mauro Tettamanti

IRCSS: Istituto Di Ricerche Farmacologiche Mario Negri

Antonio D'Ettorre

Coresearch Center for Outcomes Research and Clinical Epidemiology

Fausto Avanzini

IRCSS: Istituto Di Ricerche Farmacologiche Mario Negri

Ida Fortino

Regional Health Ministry Lombardy Region

Antonio Nicolucci

Coresearch Center for Outcomes Research and Clinical Epidemiology

Maria Carla Roncaglioni

IRCSS: Istituto Di Ricerche Farmacologiche Mario Negri

Francesco Giorgino

University of Bari: Universita degli Studi di Bari Aldo Moro

Original investigation 
Keywords: glucagon-like peptide-1 receptor agonists, sodium glucose cotransporter-2 inhibitors, antihyperglycemic drugs, death, cardiovascular outcomes

Posted Date: October 12th, 2020

DOI: https://doi.org/10.21203/rs.3.rs-89359/v1

License: (c) (1) This work is licensed under a Creative Commons Attribution 4.0 International License. Read Full License 


\section{Abstract}

\section{Background:}

GLP-1 receptor agonists (G LP-1 RA) and SGLT-2 inhibitors (SGLT-2i) are recommended in type 2 diabetes subjects with established cardiovascular (CV) disease or at high CV risk. The efficacy and safety of GLP-1 RA and SGLT-2i compared with other anti-hyperglycemic agents (AHAs) was examined in large unselected populations of Lombardy and Apulia regions in Italy.

\section{Methods:}

An observational cohort study of new users of GLP-1 RA, SGLT-2i and other AHAs was conducted from 2010 to 2018. Death and cardiovascular events were evaluated using conditional Cox models in propensity-score matched populations. Adjusted hazard ratios $(95 \%, \mathrm{Cl})$ were calculated for each region and as meta-analysis for pooled risks.

\section{Results:}

After propensity-matching, the Lombardy cohort included 18,716 and 11,683 pairs and the Apulia cohort 9,772 and 6,046 pairs for the GLP-1 RA and SGLT-2i groups, respectively. Use of GLP-1 RA was associated with lower rates of death (HR 0.61, $\mathrm{Cl} 0.56-0.65$, Lombardy; HR 0.63, Cl 0.55-0.71, Apulia), cerebrovascular disease and ischemic stroke (HR 0.70, $\mathrm{Cl} 0.63-0.79 ; \mathrm{HR} \mathrm{0.72,} \mathrm{Cl} 0.60-0.87$, Lombardy) peripheral vascular disease (HR 0.72, $\mathrm{Cl}$ 0.64-0.82, Lombardy; HR 0.80, Cl 0.67-0.98, Apulia) and, lower limb complications (HR 0.67, Cl 0.56-0.81, Lombardy; HR 0.69, Cl 0.51-0.93, Apulia). Compared to other AHAs, SGLT-2i use decreased the risk of death (HR 0.47, $\mathrm{Cl} 0.40-0.54$, Lombardy; HR 0.43, Cl 0.32-0.57, Apulia), cerebrovascular disease (HR 0.75, Cl 0.61-0.91, Lombardy, HR 0.72, Cl 0.54-0.96, Apulia), and heart failure (HR 0.56, Cl 0.46-0.70, Lombardy, HR 0.57, $\mathrm{Cl} 0.42-0.77$, Apulia). In the pooled cohorts, a reduction in heart failure was also observed with GLP-1 RA (HR 0.89, 95\% Cl 0.82-0.97). Serious adverse events were quite low in frequency.

\section{Conclusions:}

Our findings from real world practice confirm the favorable effect of GLP-1 RA and SGLT-2i on death and $\mathrm{CV}$ outcomes consistent across both regions. Thus, these drug classes should be preferentially considered in a broad type 2 diabetes population beyond subjects with CV disease.

\section{Introduction}

Patients with diabetes are at high risk for adverse outcomes from atherosclerotic cardiovascular (CV) disease ${ }^{1-4}$, heart failure (HF), and renal disease. Intensive and early control of hyperglycemia in type 2 diabetes (T2D) subjects may reduce the incidence of non-fatal myocardial infarction and coronary artery disease, while it does not affect the incidence of stroke and mortality ${ }^{5-8}$. Until recently, however, antihyperglycemic therapy did not conclusively prove to reduce overall macro-vascular events in T2D, and 
there was even concern that some medications could cause CV harms and increase mortality 9,10. However, a series of large CV outcomes trials (CVOTs) in T2D patients, principally designed to meet regulatory requirements for $\mathrm{CV}$ safety, recently assessed the effects of new anti-hyperglycemic agents (AHAs), such as glucagon-like peptide-1 receptor agonists (GLP-1 RA) and sodium glucose cotransporter2 inhibitors (SGLT-2i), in addition to standard of care. In most cases, the results of these trials showed a significant reduction of major $\mathrm{CV}$ outcomes with the investigational drug compared with placebo (i.e., standard of care) ${ }^{11,12}$. Specifically, GLP-1 RA showed a prevalent CV benefit in terms of reduced incidence of atherosclerotic events, such as non-fatal myocardial infarction (MI) and stroke, while SGLT-2i consistently reduced the risk of hospitalization for heart failure (HF). The use of both drug classes was also associated with reduction in the risk of renal endpoints, SGLT2-i acting both on the decline of glomerular filtration rate and albuminuria, GLP-1 RAs mainly on the latter ${ }^{13-20}$. Based on these results, in patients with established CV disease or at high CV risk, established kidney disease, or HF, treatment with SGLT-2i or GLP-1 RA is currently recommended as part of the glucose-lowering regimen ${ }^{21-22}$.

The clinical trials showed that treatment with GLP-1 RA and SGLT-2i has been also associated with specific adverse events, such as increased risk for gastrointestinal side effects, genitourinary tract infections, and fractures $19,23,24$. This may limit the inclusion of these drugs in the therapeutic regimen, as well as adherence and persistence to these therapies in the long-term.

Some real-world studies have also investigated the efficacy and mortality outcomes of these new drugs, showing that initiation of SGLT-2i versus other AHAs was associated with a pertinent lower incidence of hospitalization for HF and death; on the other hand, the safety outcomes were not investigated or only in

a limited sample size in this setting ${ }^{25-29}$. In addition, these observational studies have largely focused on the comparison between SGLT-2i and other AHAs, while information on population-based cohort studies comparing the efficacy and safety of GLP-1 RA versus other AHAs is more limited ${ }^{30,31}$

To assess whether the results of randomized clinical trials with the new AHAs are generalizable to the whole diabetes population is important to analyze cohorts of patients treated in daily practice. The current availability of large administrative databases allows verifying the expected clinical benefits and risks in routine clinical settings. In this study, we used administrative data from two highly populated Italian regions, Lombardy and Apulia. We aimed to describe the clinical characteristics of new users of GLP-1 RA and SGLT-2i in comparison with those receiving other AHAs and to compare the risks of death and major CV events as well the safety in these large unselected populations.

\section{Research Design And Methods}

\section{Data source}

Our study used linkable administrative health databases of Lombardy and Apulia regions in Italy, which include population registries with demographic data of all residents and detailed information on drug prescriptions and hospital records. Data are available for about 10 and 4 million inhabitants of Lombardy 
and Apulia, respectively, from 2000 to 2018 . Access to data is allowed within the agreement between the Istituto di Ricerche Farmacologiche Mario Negri (IRFMN) and Regional Health Ministry of Lombardy and, between the IRFMN and the Regional Healthcare Agency of Apulia

Healthcare in Italy is publicly funded for all residents, irrespective of social class or employment, and everyone is assigned a personal identification number kept in the National Civil Registration System. All residents are assisted by general practitioners (GPs) under the National Health System (NHS). The pharmacy prescription database contains the medication name and anatomic therapeutic chemical (ATC) classification code, quantity, and date of dispensation of drugs reimbursed by the NHS. No information is available on drugs dispensed in hospital. The hospital databases contain information on date of admission, discharge, death, primary diagnosis, and up to five co-existing clinical conditions and procedures received.

The diagnoses, uniformly coded according to the 9th International Code of Diseases (ICD-9-CM) and standardized in all Italian hospitals, are compiled by the hospital specialists directly in charge of the patients and are validated by hospitals against detailed clinical-instrumental data, as they determine reimbursement from the NHS. A unique identification code allows linkage of all databases. To ensure privacy, each identification code was automatically converted into an anonymous code before we received the dataset. In Italy, studies using retrospective aggregated-anonymous data from administrative databases do not require Ethics Committee/IRB approval nor notification.

\section{Study cohorts and follow-up}

We conducted a cohort study using the two administrative health databases from Lombardy and Apulia. Subjects 50 years and older with chronic exposure to AHAs (at least two packages in the year -ATC code $A 10^{*}$ ) from January 1, 2010, through December 31, 2018, were included in the analysis. Subjects were split into three groups according to the first exposure (new users) to one of the following drug classes: GLP-1 RA, SGLT-2i or other AHAs including metformin, sulfonylureas, glinides, thiazolidinediones, acarbose, dipeptidyl-peptidase-4 inhibitors (DPP-4i). To avoid potential bias and compare relatively similar populations, subjects who were new users for insulin (as chronic treatment) were not included in the other AHAs group. Indeed, insulin therapy may be a marker of more severe and/or advanced disease and we could not adjust for disease severity due to the lack of availability of full clinical data of these cohorts. However, a percentage of subjects within the AHAs group may have had previous insulin exposure in previous years before entering cohort, but not as a chronic treatment according to selection criteria used in this analysis. New users were defined as subject whose first exposure (index date) to one of the anti-hyperglycemic drug classes occurred in the index year with no prior exposure to any of medications belonging to the same class in the previous five years before entering the cohort. Subjects initiating GLP-1 RA and SGLT-2i were included in the study cohort from 2010 and 2015, respectively, according to the availability of these drugs in the Italian market. 
The propensity score matching (PSM) was used to reduce confounding due to imbalance in study covariates. A systematic approach to selection of variables was used to create balanced cohorts, attempting to exclude as few subjects as possible. The PMS matching was used to match GLP-1 RA and SGLT-2i cohorts with other AHAs in a 1:1 ratio using the following variables: age classes (five years intervals), sex, index year, prior exposure to insulin, duration of diabetes, and the Drug Derived Complexity Index (DDCl) as a proxy of comorbidities. The $\mathrm{DDCl}$ is a predictive score derived from drug prescriptions able to stratify the general population according to the risk of one-year and long-term mortality, as well as the risk of unplanned hospitalization and hospital readmission ${ }^{32}$. Subjects were followed-up from drug initiation until the first occurrence of i.) outcomes of interest or ii.) migration, admission to a nursing home or up to the end of follow-up (December 31, 2018). A sensitivity analysis having new users for DDP4-i as a comparator cohort was also carried out. This comparison allowed to assess the effects of GLP-1 RA and SGLT-2i versus a drug class, i.e. DPP4-i, known to exhibit neutral effects on major CV outcomes in T2D subjects ${ }^{33-36}$; moreover, GLP-1 RA, SGLT-2i and DPP-4i are only prescribed by diabetes specialists in Italy.

\section{Comorbidities and pharmacological treatments}

Comorbidities were gathered in the five years before the index date using hospital records according to ICD 9-CM as primary diagnosis and up to five co-existing conditions. Previous exposure to any AHAs class, hospital admissions and DDCl-index were collected in the previous five years, while information on the other medications of interest was retrieved in the previous twelve months. Information on duration of diabetes was collected from 2000 to 2018 (Supplementary materials).

\section{Study Outcomes}

Outcomes included the following events: death from any cause, hospital admission for cerebrovascular disease, CV disease, ischemic stroke, acute coronary syndrome, heart failure, peripheral vascular disease, lower limb complications, as primary diagnosis. Serious adverse events including hospital admission for hypoglycemia, ketoacidosis, diabetes with coma, amputation, acute renal failure, syncope, and fracture as primary diagnosis were also analyzed. All clinical events were collected using hospital admission according to the ICD 9-CM codes (Supplementary Material). Renal outcomes were not analyzed since the initiation of SGLT-2i therapy is indicated only in individuals with eGFR $>60 \mathrm{ml} / \mathrm{m}^{2} / \mathrm{min}$; this may likely select a patient cohort with better renal health compared to that treated with other AHAs, representing a bias for analyzing renal outcomes.

\section{Statistical analysis}

Baseline characteristics of patients in each groups of treatment were evaluated by using descriptive statistics. Categorical variables were described by frequencies and percentages and compared using Chi- 
squared test, continuous variables by using mean \pm standard deviation (SD), and compared using Student's t-test. Drug Derived Complexity Index (DDCl), previous hospital admission, history of diabetes and follow-up times were expressed as median and interquartile range [IQR].

Participants were matched on the logit of the propensity score using calipers of width equal to 0.1 of the standard deviation of the logit of the estimated propensity score ${ }^{37}$. Specifically, based on PSM, patients receiving GLP-1 RA or SGLT-2i were matched 1:1 with those receiving other AHAs. The adequacy (congruency) of PSM was assessed by standardized differences of post-matching patients' characteristics. To evaluate the balance between groups after matching, we calculated the standardized mean difference $(S M D)$; good balance is conventionally set at $S M D<0.10^{38}$.

Longitudinal analyses were performed in matched populations. Outcomes were calculated as crude incidence rate (IR) as the number of incident events divided by the total number of person-years at risk and expressed per 100 person-years with $95 \%$ confidence interval $(\mathrm{Cl})$. The percentage of events in each group was calculated as the number of incident events divided by the total number of persons at risk. Cox proportional hazard regression model based on time to first event was used to estimate hazard ratios (HRs) and 95\% Cl for each outcome, comparing the treatment effect of GLP-1 RA and SGLT-2i versus other AHAs (reference group). HRs were adjusted for all comorbidities reported at baseline. Outcomes were analyzed by intention-to-treat. The frequency of serious adverse events was calculated as the number of events divided by total population in each group of treatment.

Results are presented for each region separately, since the Italian Privacy Policy on data protection does not allow to export pooled data from multiple health administrative databases of distinct Italian regions. Then, pooled risks from the two regions were presented as meta-analysis for an overall summary. Isquare was used to calculate heterogeneity among the studies. A probability value of I-square $\geq 50 \%$ indicated the presence of significant heterogeneity. The fixed effects model was used in the presence of no significant interstudy heterogeneity; otherwise, the random effects model was used. The log-rank test, stratified by region, was used for comparisons, and the hazard ratios with $95 \% \mathrm{Cl}$ of events were calculated. A p-value $<0.05$ was considered statistically significant. A sensitivity analyses was computed comparing GLP-1 RA and SGLT-2i with DPP-4i. All analyses were performed using SAS version 9.4 (SAS Institute, Cary, NC, USA).

\section{Results}

Overall, during the study period, 29,634 new users of GLP-1 RA, 25,141 new users of SGLT-2i and 228,274 new users of other AHAs were identified (baseline patients characteristics before matching are reported in Supplementary material). The median follow-up time for GLP-1 RA, SGLT-2i and other AHAs, was $4.0 \pm$ 2.7, $1.7 \pm 1.0$ and $5.2 \pm 2.8$ years in Lombardy, and $3.5 \pm 2.7,1.7 \pm 0.9$ and $5.3 \pm 2.8$ years in Apulia, respectively. 
After PSM, the Lombardy study cohort included 18,716 pairs for the GLP-1 RA group and 11,683 pairs for the SGLT-2i group, while the Apulia study cohort comprised 9,772 and 6,046 for the GLP-1 RA and SGLT-2i groups, respectively (Table 1, A and B). After matching, the variables included in the PMS were wellbalanced (all standardized differences were $<0.1$ ). In general, in both regions, subjects newly prescribed a GLP-1 RA or a SGLT-2i had similar comorbidities as controls, although patients initiating SGLT-2i were more likely to have CV disease in comparison with new users of other AHAs. In the GLP-1 RA and SGLT-2i groups, $4.0-7.0 \%$ and $12-16 \%$ of patients had established cerebrovascular and CV diseases, respectively, in both Lombardy and Apulia regions (Table 1, A and B).

Patients belonging to the GLP-1 RA or SGLT-2i groups presented with slightly higher rates of background anti-hyperglycemic treatment and received slightly more antihypertensive and lipid-lowering medications as compared to the other AHAs cohort (Table 1, A and 1B).

Differences between the GLP-1 RA and SGLT-2i groups in both regions were observed in mean age (6768 years in SGLT-2i group versus 64-65 years in GLP-1 RA group), history of diabetes (a higher percentage of subjects in the SGLT-2i group had a duration of T2DM $\geq 10$ years compared to the GLP-1 RA group), and previous prescription of insulin (34\% in SGLT-2i group versus $29 \%$ in GLP-1 RA group).

Risks of death and clinical outcomes in propensity score-adjusted populations by treatment status for Lombardy and Apulia regions are reported in Fig. 1, A and B, and Fig. 2, A and B.

In the Lombardy cohort, initiation of GLP-1 RA was associated with a lower risk of death (HR $0.61,95 \% \mathrm{Cl}$ $0.56-0.65)$, cerebrovascular disease (HR $0.70,95 \% \mathrm{Cl} 0.63-0.79$ ), ischemic stroke (HR $0.72,95 \% \mathrm{Cl} 0.60-$ 0.87), peripheral vascular disease ( $\mathrm{HR} 0.72,95 \% \mathrm{Cl} 0.64-0.82$ ), and lower limb complications (HR 0.67 , 95\% $\mathrm{Cl} 0.56-0.81)$ in comparison with the other AHAs group. In the Apulia cohort, subjects who received GLP-1 RA also exhibited a lower risk of death (HR 0.63, 95\% Cl 0.55-0.71), peripheral vascular disease (HR 0.80,95\% Cl 0.67-0.98), and lower limb complications (HR 0.69, 95\% $\mathrm{Cl} 0.51-0.93$ ) with respect to those treated with other AHAs.

In the Lombardy cohort, initiation of SGLT-2i was associated with a lower risk of death (HR $0.47,95 \% \mathrm{Cl}$ $0.40-0.54$ ), cerebrovascular disease (HR $0.75,95 \% \mathrm{Cl} 0.61-0.91)$, and heart failure (HR $0.56,95 \% \mathrm{Cl}$ 0.46-0.70) in comparison with the other AHAs group. Similar results were obtained in the Apulia cohort with reductions of risks of death ( $\mathrm{HR} 0.43,95 \% \mathrm{Cl} 0.32-0.57)$, cerebrovascular disease (HR $0.72,95 \% \mathrm{Cl}$ 0.54-0.96), and heart failure (HR $0.57,95 \% \mathrm{Cl} 0.42-0.77$ ) compared with the other AHAs group.

When results from the two cohorts were pooled, a small but significant reduction in the risk of hospitalization for heart failure (HR 0.89, 95\% Cl 0.82-0.97) with GLP-1 RA compared with other AHAs was also apparent (Fig. 1S Supplementary Material).

During follow-up, the rate of serious adverse events was quite low in each region. In general, fractures were documented more frequently; however, the rate of this event was slightly lower in the SGLT-2i group (around 1\%) than in the GLP-1 RA and AHAs groups (2.5\%) (Table 2). 
Results of the preplanned sensitivity analysis comparing GLP-1 RA or SGLT-2i with DPP-4i for each region are reported in the Supplementary material, showing baseline characteristics of matched and unmatched populations as well as risks for all considered outcomes. After PSM, the population of the two cohorts were well-matched for multiple clinical variables (all standardized differences were $<0.1$, except for renal disease and heart failure in some of the comparisons; Supplementary Material). In comparison with subjects who received DPP-4i, those initiating GLP-1 RA showed statistically significant risk reductions for death, cerebrovascular disease, peripheral vascular disease, lower limb complications (Lombardy cohort, Table S9), and death and lower limb complications (Apulia cohort, Table S11), while those initiating SGLT-2i had risk reductions for death, cerebrovascular disease and heart failure (Lombardy cohort, Table S10), and death and heart failure (Apulia cohort, Table S12). These results were similar to those observed in comparison with other AHAs.

\section{Discussion}

In this analysis, we have examined large cohorts of T2D initiating treatment with GLP-1 RA or SGLT-2i compared with other anti-hyperglycemic therapies, including DPP-4i, in routine clinical settings. The available information refers to data from two distinct Italian regions, Lombardy and Apulia, which allows an assessment of the epidemiology of diseases unbiased by patient selection. In Italy, all subjects are covered by the NHS, according to the distinct reimbursement policies, with a high level of completeness regarding drug prescriptions, diagnosis, and length of observation. Administrative databases have been increasingly recognized as a reliable tool to prospectively describe the pharmaco-epidemiology and outcomes of large patients cohorts representing the real clinical care, collecting data over time in a standardized way and at low cost ${ }^{39,40}$. We found that initiation of GLP-1 RA therapy was associated with consistent risk reductions in all-cause death and hospitalization for peripheral vascular disease and lower limb complications, with additional risk reductions for cerebrovascular disease and ischemic stroke that were evident in the Lombardy cohort. Initiation of SGLT-2i was associated with risk reductions of allcause death and hospitalization for cerebrovascular disease, and heart failure. These risk reductions occurred in comparison with the initiation of other AHAs (except insulin), and most differences were also observed after comparing the new users of GLP-1 RA or SGLT-2i with patients initiating DPP-4i.

As of today, results from seven CVOTs with GLP-1 RA have been disclosed. The definition of secondary prevention cohorts according to previous CV disease of the enrolled population varied among these trials, and so was the proportion of such patients ${ }^{11}$. Nevertheless, ELIXA and HARMONY Outcome involved only patients with recent acute coronary syndrome or any CV disease, respectively; by contrast, REWIND assessed a population with $70 \%$ of individuals without prior CV disease and with the lowest proportion (only 8\%) affected from congestive HF. Large observational studies assessing CV outcomes with GLP-1 RA are not available at present. The CVOTs with SGLT-2i enrolled patients at high CV risk (with percentages of subjects with atherosclerotic CV disease ranging from 41\% in DECLARE-TIMI 58 to $65 \%$ in CANVAS and $100 \%$ in EMPA-REG). In these trials, at baseline, subjects with HF ranged from $10-14 \%$ of the population, while between $6.5 \%$ and $23.3 \%$ had a stroke ${ }^{12}$. In the real-world observational studies 
assessing CV outcomes with SGLT-2i, the CV risk level of the examined populations is very different. CVDREAL and CVD-REAL-2 included $13 \%$ and $26 \%$ of patients with T2D and established CV disease, respectively ${ }^{25,29}$, while in CVD-REAL Nordic, this proportion was $25 \%{ }^{41}$. In the CVD-REAL program, the proportion of patients with $\mathrm{HF}$ at baseline ranged from 3-6.8\%. By contrast, EASEL, involved only patients with T2D and established CV disease ${ }^{42}$. In our study, the proportion of individuals with CV disease was between $12-16 \%$ and that with HF between 3-6\% (Table 1). Moreover, these proportions did not appear to differ between Lombardy and Apulia. Therefore, the population examined here had a level of CV risk largely lower than in the CVOTs with GLP-1 RA or SGLT-2i and somewhat similar to that in the observational study with SGLT-2i CVD-REAL.

In our analysis, first use of GLP-1 RA was associated with 37-39\% reduced risk of all-cause death and reductions of peripheral vascular disease and lower limb complications. Meta-analysis of the GLP-1 RA CVOTs also showed an overall $12 \%$ reduction in the risk of all-cause mortality ${ }^{14}$, while the effects on peripheral vascular disease and lower limb complications were not considered as primary or secondary endpoints in those trials. The risk reductions for cerebrovascular disease and ischemic stroke observed in the Lombardy cohort is of interest, given that in some GLP-1 RA CVOTs, such as REWIND ${ }^{16}$ and SUSTAIN-6 ${ }^{43}$ the risk of stroke was also reduced with the investigational GLP-1 RA. In a recent study on a relatively smaller cohort from North-East Italy, including $\sim 2,800$ propensity score matched initiators of GLP-1RA or DPP-4i, 15\% with pre-existing cardiovascular disease, reduced rates of a composite of allcause death, myocardial infarction, or stroke (HR: $0.67 ; 95 \%$ C.I. $0.53-0.86)$ were found in patients treated with GLP-1RA compared to DPP4i ${ }^{31}$.

In our study, first use of SGLT-2i was associated with large risk reductions of all-cause death (by 53-57\%) and HF (by $43-44 \%$ ), as well as of cerebrovascular disease (by $25-28 \%$ ). The risk reduction in HF hospitalization has been consistently observed in all CVOTs and observational studies with SGLT-2i, while all-cause death was reduced in EMPA-REG and in the observational studies. Of note, the effect size of those reductions resembles the one found in the present analysis. Results from Lombardy and Apulia also consistently show a reduction in the risk of cerebrovascular disease. While the risk of fatal or nonfatal stroke was not changed in the three major SGLT-2i CVOTs, the observational study CVD-REAL 2 (conducted in Australia, Canada, Israel, Japan, Singapore, and South Korea on 235,064 patients with T2DM) also showed an association of SGLT-2i use with a significantly reduced risk of stroke (HR: 0.68 ; $95 \% \mathrm{Cl}: 0.55,0.84)^{29}$, in line with this analysis.

The results of the meta-analysis between Lombardy and Apulia study cohorts largely confirmed the results obtained from the main analysis of the individual regions but also provided further information. Pooling the data, initiation of GLP-1 RA was not associated with a lower risk of cerebrovascular disease and ischemic stroke, as observed in the Lombardy region. However, GLP-1 RA initiation was associated with a small but significant lower risk of HF. This observation deserves further investigation with dedicated studies. 
Similar risk reductions were found for all-cause death and other CV outcomes comparing initiation of GLP-1 RA with initiation of DPP-4i, while patients initiating SGLT-2i had consistent risk reductions for death and HF in both regional cohorts. This data is of interest, since initiation of GLP-1 RA and SGLT-2i is being compared here with a drug class, DPP4-i, that also does not cause hypoglycemia or weight gain. Moreover, the two treatment strategies were equally positioned in the Italian treatment algorithm and could be prescribed only by diabetes specialists. Such direct comparisons have not been addressed in the CVOTs, while a single additional analysis from CVD-REAL Nordic revealed that the SGLT-2i dapagliflozin was also associated with significantly lower incidence of hospitalization for HF, all-cause mortality and major adverse CV events in comparison with DPP-4i ${ }^{44}$; moreover, an interim analysis from the ongoing EMPRISE observational study including 224,528 patients with T2D with and without established CV disease reported that initiation of SGLT-2i was associated with a $48 \%$ lower rate of hospitalization for HF in comparison with DPP-4i 27.

In general, our analysis shows a low occurrence of adverse effects that could be captured using the administrative database, including ketoacidosis, amputations, renal failure, syncope, and fractures, which represent the most worrisome adverse events associated with SGLT-2i use emerging from randomized controlled trials 45 .

\section{Strengths And Limitations}

To our knowledge, this is the first study of real-world evidence that evaluated the effect of GLP-1 RA on mortality and major adverse CV events in comparison with other AHAs. The analysis was conducted on a large number of patients after PSM (30,399 in Lombardy and 15,818 in Apulia), initiating both GLP-1 RA and SGLT-2i. Results found with GLP-1 RA and SGLT-2i in comparison with other AHAs were largely confirmed when DPP-4i were used as a comparator. The length of observation was almost four years for GLP-1 RA and two years for SGLT-2i. Finally, Lombardy and Apulia are two representative regions of Northern and Southern Italy, respectively; the results of this analysis, therefore, could be potentially generalized to the whole Italian population.

Our study also has several limitations that are typical of all the studies on administrative databases. First on the basis of available information, we are unable to distinguish between type 1 and type 2 diabetes, so both are considered in this study even though more than $90 \%$ are estimated to have T2D ${ }^{46}$. Moreover, some specific information on clinical variables or laboratory tests (such as HbA1C, BMI, eGFR) that deserves attention mainly referring to glycemic values, lifestyle habits, CV risk factors, or NYHA class is not available. Thus, we could not correct for these confounding factors, as well as to distinguish between primary versus secondary prevention.

Our results must be interpreted with caution since our study was not randomized, and some clinically important characteristics might be not have been taken into account. Finally, different length of follow-up was considered for GLP-1 RA and SGLT-2i (much shorter for SGLT-2i), and somewhat larger use of antihypertensive and lipid-lowering medications was found in the GLP-1 RA and SGLT-2i groups. 
A potential issue with large pharmaco-epidemiological studies, such as CVD-REAL, EASEL, EMPRISE and the present analysis, is the possibility of 'immortal time bias', which could exaggerate the observed benefits regarding rates of all-cause death. Immortal time bias could occur when two patient groups are formed within a time interval in a hierarchical manner ${ }^{47,48}$. While propensity matching of patients treated with SGLT-2i, GLP-1 RA or other AHAs minimizes the risk of such bias, residual confounding could still influence results even following PSM.

\section{Conclusions}

Most findings of reduction of all-cause death, vascular outcomes and HF were consistent in the two Italian regions, and the pattern of protection for each class seen in the CVOTs and, when available, observational studies from real-world evidence was largely confirmed by this analysis (e.g. hospitalization for HF with SGLT-2i, effects on CV disease and stroke with GLP-1 RA). The favorable effects of both GLP-1 RA and SGLT-2i on all-cause death and several CV endpoints, as well as the safety outcomes, over other commonly used glucose-lowering therapies and in a population with a low prevalence of CV complications suggests that GLP-1 RA and SGLT-2i should be preferentially used not only in high CV risk T2D patients.

\section{Abbreviations}

ACE-l: angiotensin-converting enzyme inhibitors, AHAs: antihyperglycemic agents, ARBs: angiotensin II receptor agonist blockers, Cl: Confidence interval, CV: cardiovascular, DCCI: Drug Derived Complexity Index, DPP-4i: dipeptidyl peptidase 4 inhibitors, GLP-1 RA: glucagon-like peptide-1 receptor agonists, HF: Heart failure, HR: Hazard ratio, IQR: interquartile range, IR: incidence rate, SD: standard deviation, SGLT-2i: sodium glucose cotransporter-2 inhibitors, SMD: standardized mean difference, PMS: propensity score matching, T2DM: Type 2 Diabetes Mellitus.

\section{Declarations}

\section{Acknowledgements}

We thank Simone Schiatti and Giovanna Rigotti from Lombardia Informatica S.p.A, Alfredo Bevilacqua from SANTER Reply S.p.A and, Igor Monti from the IRFMN who kindly assisted us with data collection. We thank the Director of the Regional Agency for Health and Social Affairs of Puglia (AReSS-Puglia) for data availability and collaboration. We also thank Fiorenza Clerici from the IRFMN for secretarial support.

\section{Authors' Contributions}

$\mathrm{MB}, \mathrm{SG}, \mathrm{VL}, \mathrm{AN}, \mathrm{MCR}, \mathrm{FG}$ contributed to the development of the study concept and design interpretation of data and writing of the Article. PC, FR, MT, AD'E, IF contributed to data collection, analysis, interpretation of data and critical review of the Article. FA contributed to data report finalisation, critical review and revision of the Article. 


\section{Funding}

This study was supported by grant from the Health Ministry of Lombardy and Apulia that was involved in data collection. Access to data is allowed within the Agreement between the Istituto di Ricerche Farmacologiche Mario Negri and Regional Health Ministry of Lombardy and, between the Istituto di Ricerche Farmacologiche Mario Negri and the Regional Healthcare Agency of Apulia.

\section{Availability of data and materials}

Access to row data is allowed only to the investigators within the Agreement. Programme code can be shared following the permission granted from the Regions involved in the Agreement with Istituto di Ricerche Farmacologiche Mario Negri.

\section{Ethics approval and consent to participate}

In Italy, studies using retrospective aggregated-anonymous data from administrative databases do not require Ethics Committee/IRBapproval nor notification.

\section{Consent for publications}

Not applicable

\section{Competing interest}

S.G.: received research funding from Novartis and has been a consultant for, or received honoraria from Abbott Diabetes Care, AstraZeneca, Boehringer Ingelheim, Bruno Farmaceutici, Eli Lilly, Hikma Pharmaceuticals, Janssen, Johnson \&Johnson, Menarini, Merck Sharp \& Dohme, Molteni Farmaceutici, Mundipharma, Novartis, Novo Nordisk, Sanofi, and Takeda

A.N.: Research Grants form AlfaSigma, Astra Zeneca, Eli Lilly, Medtronic, Novo Nordisk, Pikdare, Theras, Sanofi, Shionogi, SOBI

F.G.: is 1) research support for Eli Lilly; Lifescan, Takeda; 2) a consultant for Boehringer Ingelheim; Lifescan; Merck Sharp \& Dohme; Sanofi; AstraZeneca; Medimmune; Roche Diabetes Care; and 3) on the advisory boards for AstraZeneca; Eli Lilly; Novo Nordisk; Roche Diabetes Care; and Sanofı.

M.B.; V.L.; P.C.; F.R; M.T.; A. D’E.; F.A.; I.F.; MC.R.: declare no conflict of interest.

\section{References}

1. Roger VL , Go AS , Lloyd-Jones DM et al. American Heart Association Statistics Committee and Stroke Statistics Subcommittee. Heart Disease and Stroke statistics-2011 Update: A Report From the American Heart Association. Circulation 2011;123(4):e18-e209. doi:

10.1161/CIR.0b013e3182009701. 
2. Donahoe SM, Stewart GC, McCabe CH, et al. Diabetes and Mortality Following Acute Coronary Syndromes. 2007;298(7):765-75. doi: 10.1001/jama.298.7.765.

3. Ahmad FS, Ning H, Rich JD, Yancy CW, Lloyd-Jones DM, Wilkins JT. Hypertension, Obesity, Diabetes, and Heart Failure-Free Survival: The Cardiovascular Disease Lifetime Risk Pooling Project. JACC Heart Fail. 2016;4(12):911-919. doi: 10.1016/j.jchf.2016.08.001.

4. Ritz E, Orth SR. Nephropathy in Patients with Type 2 Diabetes Mellitus. N Engl J Med. 1999;341(15):1127-33. doi: 10.1056/NEJM199910073411506.

5. UK Prospective Diabetes Study (UKPDS) Group. Effect of Intensive Blood-Glucose Control With Metformin on Complications in Overweight Patients With Type 2 Diabetes (UKPDS 34). Lancet 1998;352(9131):854-65. doi.org/10.1016/S0140-6736(98)07037-8.

6. Giorgino F, Home PD, Tuomilehto J. Glucose Control and Vascular Outcomes in Type 2 Diabetes: Is the Picture Clear? Diabetes Care. 2016;39 Suppl 2: S187-95. doi: 10.2337/dc16-er09.

7. Holman RR, Paul SK, Bethel MA, Matthews DR, HAW Neil. 10-year Follow-Up of Intensive Glucose Control in Type 2 Diabetes. N Engl J Med. 2008;359(15):1577-89. doi: 10.1056/NEJMoa0806470.

8. Mannucci E, Monami M, Lamanna C, Gori F, Marchionni Prevention of cardiovascular disease through glycemic control in type 2 diabetes: a meta-analysis of randomized clinical trials. Nutr Metab Cardiovasc Dis. 2009;19(9):604-12. doi: 10.1016/j.numecd.2009.03.021.

9. Davies MJ, D'Alessio DA, Fradkin J, et al. Management of Hyperglycemia in Type 2 Diabetes, 2018. A Consensus Report by the American Diabetes Association (ADA) and the European Association for the Study of Diabetes (EASD). Diabetes Care. 2018;41(12):2669-2701. doi: 10.2337/dci18-0033.

10. Monami M, Genovese S, Mannucci E. Cardiovascular Safety of Sulfonylureas: A Meta-Analysis of Randomized Clinical Trials. Diabetes Obes Metab. 2013;15(10):938-53. doi: 10.1111/dom.12116.

11. Caruso I, Cignarelli A, Giorgino F. Heterogeneity and Similarities in GLP-1 Receptor Agonist Cardiovascular Outcomes Trials. Trends Endocrinol Metab. 2019;30(9):578-589. doi: 10.1016/j.tem.2019.07.004.

12. Giorgino F, Vora J, Fenici P, Solini A. Cardiovascular protection with sodium-glucose co-transporter-2 inhibitors in type 2 diabetes: Does it apply to all patients? Diabetes Obes Metab. doi: 10.1111/dom.14055

13. Bethel MA, Patel RA, Merrill P, EXSCEL Study Group et al. Cardiovascular Outcomes With GlucagonLike peptide-1 Receptor Agonists in Patients With Type 2 Diabetes: A Meta-Analysis. Lancet Diabetes Endocrinol. 2018;6(2):105-113. doi: 10.1016/S2213-8587(17)30412-6.

14. Kristensen SL, Rørth R, Jhund PS, et al. Cardiovascular, mortality, and kidney outcomes with GLP-1 receptor agonists in patients with type 2 diabetes: a systematic review and meta-analysis of cardiovascular outcome trials. Lancet Diabetes Endocrinol. 2019;7(10):776-785. doi: 10.1016/S22138587(19)30249-9

15. Zelniker TA, Wiviott SD, Raz I, et al. Comparison of the Effects of Glucagon-Like Peptide Receptor Agonists and Sodium-Glucose Cotransporter 2 Inhibitors for Prevention of Major Adverse 
Cardiovascular and Renal Outcomes in Type 2 Diabetes Mellitus. Circulation. 2019;139(17):20222031. doi: 10.1161/CIRCULATIONAHA.118.038868.

16. Gerstein HC, Colhoun HM, Dagenais GR, et al. REWIND Investigators. Dulaglutide and Cardiovascular Outcomes in Type 2 Diabetes (REWIND): A Double-Blind, Randomised Placebo-Controlled Trial. Lancet. 2019;394(10193):121-130. doi: 10.1016/S0140-6736(19)31149-3.

17. Gerstein HC, Colhoun HM, Dagenais GR, et al. REWIND Dulaglutide and Renal Outcomes in Type 2 Diabetes: An Exploratory Analysis of the REWIND Randomised, Placebo-Controlled Trial. Lancet. 2019;394(10193):131-138. doi: 10.1016/S0140-6736(19)31150-X.

18. Perkovic V, Jardine MJ, Neal B, et al. CREDENCE Trial Investigators. Canagliflozin and Renal Outcomes in Type 2 Diabetes and Nephropathy. N Engl J Med. 2019;380(24):2295-2306. doi: 10.1056/NEJMoa1811744.

19. Rådholm K, Wu J H, Wong MG et al. Effects of Sodium-Glucose cotransporter-2 Inhibitors on Cardiovascular Disease, Death and Safety Outcomes in Type 2 Diabetes - A Systematic Review. Diabetes Res Clin Pract. 2018; 140:118-128. doi: 10.1016/j.diabres.2018.03.027.

20. Prattichizzo F, La Sala L, Rydén L, et al. Glucose-lowering Therapies in Patients with Type 2 Diabetes and Cardiovascular Diseases. Eur J Prev Cardiol. 2019;26(2_suppl):73-80. doi: $10.1177 / 2047487319880040$.

21. American Diabetes Association. Pharmacologic Approaches to Glycemic Treatment: Standards of Medical Care in Diabetes-2020. Diabetes Care. 2020;43(Suppl 1): S98-S110. doi: 10.2337/dc20-S009.

22. Cosentino F, Grant PJ, Aboyans V, et al. ESC Scientific Document Group. 2019 ESC Guidelines on Diabetes, Pre-Diabetes, and Cardiovascular Diseases Developed in Collaboration With the EASD. Eur Heart J. 2020;41(2):255-323. doi: 10.1093/eurheartj/ehz486.

23. Abrahami D, Douros A, Hui Yin, Oriana H Y Yu, Laurent Azoulay. Sodium-Glucose Cotransporter 2 Inhibitors and the Risk of Fractures Among Patients with Type 2 Diabetes. Diabetes Care. 2019;42(9):e150-e152. doi: 10.2337/dc19-0849.

24. Røder ME. Major Adverse Cardiovascular Event Reduction With GLP-1 and SGLT2 Agents: Evidence and Clinical Potential. Ther Adv Chronic Dis. 2018;9(1):33-50. doi: 10.1177/2040622317735283.

25. Kosiborod M, Cavender MA, Fu AZ, et al. CVD-REAL Investigators and Study Group. Lower Risk of Heart Failure and Death in Patients Initiated on Sodium-Glucose Cotransporter-2 Inhibitors Versus Other Glucose-Lowering Drugs: The CVD-REAL Study (Comparative Effectiveness of Cardiovascular Outcomes in New Users of Sodium-Glucose Cotransporter-2 Inhibitors). Circulation. 2017;136(3):249259. doi: 10.1161/CIRCULATIONAHA.117.029190.

26. Udell JA, Yuan Z, Rush T, Sicignano NM, Galitz M, Rosenthal N. Cardiovascular Outcomes and Risks After Initiation of a Sodium Glucose Cotransporter 2 Inhibitor: Results From the EASEL PopulationBased Cohort Study (Evidence for Cardiovascular Outcomes With Sodium Glucose Cotransporter 2 Inhibitors in the Real World). Circulation. 2018;137(14):1450-1459.

10.1161/CIRCULATIONAHA.117.031227. 
27. Patorno E, Pawar A, Franklin JM, et al. Empagliflozin and the Risk of Heart Failure Hospitalization in Routine Clinical Care. Circulation. 2019;139(25):2822-2830. doi:

10.1161/CIRCULATIONAHA.118.039177.

28. Pasternak B, Ueda P, Eliasson B, et al. Use of Sodium Glucose Cotransporter 2 Inhibitors and Risk of Major Cardiovascular Events and Heart Failure: Scandinavian Register Based Cohort Study. BMJ. 2019;366:I4772. doi: 10.1136/bmj.|4772.

29. Kosiborod M, Lam CSP, Kohsaka S, et al. CVD-REAL Investigators and Study Group. Cardiovascular Events Associated With SGLT-2 Inhibitors Versus Other Glucose-Lowering Drugs: The CVD-REAL 2 Study. J Am Coll Cardiol. 2018;71(23):2628-2639. doi: 10.1016/j.jacc.2018.03.009.

30. Patorno E, Everett BM, Goldfine AB, et al. Comparative Cardiovascular Safety of Glucagon-Like peptide-1 Receptor Agonists Versus Other Antidiabetic Drugs in Routine Care: A Cohort Study. Diabetes Obes Metab. 2016 Aug;18(8):755-65. doi: 10.1111/dom.12665.

31. Longato E, Di Camillo B, Sparacino G, Tramontan L, Avogaro A, Fadini Better Cardiovascular Outcomes of Type 2 Diabetic Patients Treated With GLP-1 Receptor Agonists Versus DPP-4 Inhibitors in Clinical Practice. Cardiovasc Diabetol. 2020 Jun 10;19(1):74.doi: 10.1186/s12933-020-01049-w.

32. Robusto F, Lepore V, D'Ettorre A, et al. The Drug Derived Complexity Index (DDCl) Predicts Mortality, Unplanned Hospitalization and Hospital Readmissions at the Population Level. PLoS One. 2016 Feb 19;11(2):e0149203. doi: 10.1371/journal.pone.0149203.

33. Mosenzon O, Leibowitz G, Bhatt DL, et al. Effect of Saxagliptin on Renal Outcomes in the SAVORTIMI 53 Trial. Diabetes Care. 2017;40(1):69-76. doi: 10.2337/dc16-0621.

34. Bethel MA, Engel SS, Stevens SR et al. TECOS Study Group. Progression of Glucose-Lowering Diabetes Therapy in TECOS. Endocrinol Diabetes Metab. 2018;2(1): doi: 10.1002/edm2.53.

35. White WB, Heller SR, Cannon CP, Howitt H, Khunti K, Bergenstal RM. EXAMINE Investigators. Alogliptin in Patients With Type 2 Diabetes Receiving Metformin and Sulfonylurea Therapies in the EXAMINE Am J Med. 2018;131(7):813-819. doi: 10.1016/j.amjmed.2018.02.023.

36. Rosenstock J, Perkovic V, Johansen OE, et al. CARMELINA Investigators. Effect of Linagliptin vs Placebo on Major Cardiovascular Events in Adults With Type 2 Diabetes and High Cardiovascular and Renal Risk: The CARMELINA Randomized Clinical Trial. JAMA. 2019;321(1):69-79. doi: 10.1001/jama.2018.18269.

37. Rosenbaum PR, Rubin DB. The Bias Due to Incomplete Matching. Biometrics. 1985;41(1):103-16. doi: $10.2307 / 2530647$.

38. Statistics Denmark. (DAFFODIL database). Statistics Denmark, Copenhagen, Denmark. http://www.dst.dk/en. Last Accessed: November, 25, 2019.

39. Schneeweiss S, Avorn J. A review of uses of health care utilization databases for epidemiologic research on therapeutics. J Clin Epidemiol. 2005;58(4):323-37. doi: 10.1016/j.jclinepi.2004.10.012.

40. Corrao G, Mancia G. Generating evidence from computerized healthcare utilization databases. Hypertension. 2015; 65(3):490-498. doi: 10.1161/HYPERTENSIONAHA.114.04858. 
41. Birkeland $\mathrm{KI}$, Jørgensen ME, Carstensen B, et al. Cardiovascular mortality and morbidity in patients with type 2 diabetes following initiation of sodium-glucose co-transporter-2 inhibitors versus other glucose-lowering drugs (CVD-REAL Nordic): a multinational observational analysis. Lancet Diabetes Endocrinol. 2017; 5(9):709-717. doi: 10.1016/S2213-8587(17)30258-9.

42. Udell JA, Yuan Z2, Rush T, Sicignano NM, Galitz M, Rosenthal N. Cardiovascular Outcomes and Risks After Initiation of a Sodium Glucose Cotransporter 2 Inhibitor: Results from the EASEL PopulationBased Cohort Study (Evidence for Cardiovascular Outcomes with Sodium Glucose Cotransporter 2 Inhibitors in the Real World). 2018; 137(14):1450-1459. doi: 10.1161/CIRCULATIONAHA.117.031227.

43. Husain M, Bain SC, Jeppesen OK et al. Semaglutide (SUSTAIN and PIONEER) Reduces Cardiovascular Events in Type 2 Diabetes Across Varying Cardiovascular Risk. Diabetes Obes Metab. 2020 Mar;22(3):442-451. doi: 10.1111/dom.13955.

44. Persson F, Nyström T, Jørgensen ME, et al. Dapagliflozin Is Associated With Lower Risk of Cardiovascular Events and All-Cause Mortality in People With Type 2 Diabetes (CVD-REAL Nordic) When Compared With Dipeptidyl peptidase-4 Inhibitor Therapy: A Multinational Observational Study. Diabetes Obes Metab. 2018; 20(2):344-351. doi: 10.1111/dom.13077.

45. Scheen AJ. An update on the safety of SGLT2 inhibitors. Expert Opin Drug Saf. 2019; 18(4):295-311. doi: 10.1080/14740338.2019.1602116.

46. American Diabetes Association. Diagnosis and classification of diabetes mellitus. Diabetes Care. 2005; 28 Suppl 1:S37-42. doi: 10.2337/diacare.28.suppl_1.s37.

47. Samy Suissa. Lower Risk of Death With SGLT2 Inhibitors in Observational Studies: Real or Bias? Diabetes Care. 2018 Jan;41(1):6-10. doi: 10.2337/dc17-1223.

48. Thuresson M, Cavender MA, Fu AZ, et al. CVD-REAL Investigators and Study Group. Comment on Suissa. Lower Risk of Death with SGLT2 Inhibitors in Observational Studies: Real or Bias? Diabetes Care. 2018; 41(6):e106-e108. doi: 10.2337/dc18-0338.

\section{Tables}


Table 1

A. Baseline characteristics of matched population according to treatment status in Lombardy region from 2010 to 2018

\begin{tabular}{|c|c|c|c|c|c|c|}
\hline \multirow[b]{2}{*}{ Variables } & \multicolumn{3}{|c|}{ Matched Population } & \multicolumn{3}{|c|}{ Matched Population } \\
\hline & $\begin{array}{l}\text { GLP-1 } \\
\text { RA } \\
(\mathrm{N}= \\
18,716)\end{array}$ & $\begin{array}{l}\text { Other } \\
\text { AHAs } \\
(N= \\
18,716)\end{array}$ & $\begin{array}{l}\text { Standardized } \\
\text { differences }\end{array}$ & $\begin{array}{l}\text { SGLT-2i } \\
(N= \\
11,683)\end{array}$ & $\begin{array}{l}\text { Other } \\
\text { AHAs } \\
(\mathrm{N}= \\
11,683)\end{array}$ & $\begin{array}{l}\text { Standardizec } \\
\text { differences }\end{array}$ \\
\hline Mean age $(+S D)$ & $\begin{array}{l}65.4 \pm \\
8.0\end{array}$ & $\begin{array}{l}65.5 \pm \\
8.0\end{array}$ & -0.01 & $\begin{array}{l}68.2 \pm \\
7.2\end{array}$ & $\begin{array}{l}68.8 \pm \\
8.3\end{array}$ & -0.07 \\
\hline Gender (Female) & $\begin{array}{l}8355 \\
(44.6)\end{array}$ & $\begin{array}{l}8248 \\
(44.1)\end{array}$ & 0.01 & $\begin{array}{l}4433 \\
(37.9)\end{array}$ & $\begin{array}{l}4501 \\
(38.5)\end{array}$ & -0.01 \\
\hline \multicolumn{7}{|l|}{$\begin{array}{l}\text { Comorbidities of } \\
\text { interest, } n(\%)\end{array}$} \\
\hline $\begin{array}{l}\text { Cerebrovascular } \\
\text { disease }\end{array}$ & $\begin{array}{l}695 \\
(3.7)\end{array}$ & $\begin{array}{l}935 \\
(5.0)\end{array}$ & -0.06 & $\begin{array}{l}512 \\
(4.4)\end{array}$ & $\begin{array}{l}647 \\
(5.5)\end{array}$ & -0.05 \\
\hline $\begin{array}{l}\text { Cardiovascular } \\
\text { disease }\end{array}$ & $\begin{array}{l}2201 \\
(11.8)\end{array}$ & $\begin{array}{l}2273 \\
(12.1)\end{array}$ & -0.01 & $\begin{array}{l}1784 \\
(15.3)\end{array}$ & $\begin{array}{l}1456 \\
(12.4)\end{array}$ & 0.08 \\
\hline Heart failure & $\begin{array}{l}670 \\
(3.6)\end{array}$ & $\begin{array}{l}816 \\
(4.4)\end{array}$ & -0.03 & $\begin{array}{l}428 \\
(3.6)\end{array}$ & $\begin{array}{l}641 \\
(5.5)\end{array}$ & -0.08 \\
\hline $\begin{array}{l}\text { Peripheral vascular } \\
\text { disease }\end{array}$ & $\begin{array}{l}627 \\
(3.4)\end{array}$ & $\begin{array}{l}757 \\
(4.0)\end{array}$ & -0.03 & $\begin{array}{l}454 \\
(3.9)\end{array}$ & $\begin{array}{l}488 \\
(4.2)\end{array}$ & -0.01 \\
\hline $\begin{array}{l}\text { Lower limb } \\
\text { complication }\end{array}$ & $\begin{array}{l}154 \\
(0.8)\end{array}$ & $\begin{array}{l}260 \\
(1.4)\end{array}$ & -0.05 & $\begin{array}{l}111 \\
(0.9)\end{array}$ & $\begin{array}{l}184 \\
(1.5)\end{array}$ & -0.05 \\
\hline Renal disease & $\begin{array}{l}318 \\
(1.7)\end{array}$ & $\begin{array}{l}613 \\
(3.3)\end{array}$ & -0.10 & $\begin{array}{l}131 \\
(1.1)\end{array}$ & $\begin{array}{l}460 \\
(3.9)\end{array}$ & -0.18 \\
\hline Neuropathy & $\begin{array}{l}415 \\
(2.2)\end{array}$ & $\begin{array}{l}383 \\
(2.0)\end{array}$ & 0.01 & $\begin{array}{l}158 \\
(1.3)\end{array}$ & $\begin{array}{l}133 \\
(1.1)\end{array}$ & 0.01 \\
\hline Diabetic retinopathy & $19(0.1)$ & $29(0.2)$ & -0.01 & $\begin{array}{l}15 \\
(0.1)\end{array}$ & $\begin{array}{l}19 \\
(0.1)\end{array}$ & -0.00 \\
\hline $\begin{array}{l}\text { Chronic obstructive } \\
\text { pulmonary disease }\end{array}$ & $\begin{array}{l}661 \\
(3.5)\end{array}$ & $\begin{array}{l}808 \\
(4.3)\end{array}$ & -0.04 & $\begin{array}{l}406 \\
(3.5)\end{array}$ & $\begin{array}{l}566 \\
(4.8)\end{array}$ & -0.06 \\
\hline Cancer & $\begin{array}{l}1244 \\
(6.6)\end{array}$ & $\begin{array}{l}1558 \\
(8.3)\end{array}$ & -0.06 & $\begin{array}{l}675 \\
(5.8)\end{array}$ & $\begin{array}{l}929 \\
(7.9)\end{array}$ & -0.08 \\
\hline \multicolumn{7}{|l|}{$\begin{array}{l}\text { Antihyperglycemic } \\
\text { drugs, } \mathrm{n}(\%)\end{array}$} \\
\hline GLP-1 RA & $0(0.0)$ & $\begin{array}{l}134 \\
(0.7)\end{array}$ & 0.11 & $\begin{array}{l}183 \\
(1.6)\end{array}$ & $\begin{array}{l}45 \\
(0.4)\end{array}$ & 0.12 \\
\hline SGLT-2i & $0(0.0)$ & $4(0.0)$ & -0.00 & $0(0.0)$ & $0(0.0)$ & 0.00 \\
\hline
\end{tabular}




\begin{tabular}{|c|c|c|c|c|c|c|}
\hline \multirow[b]{2}{*}{ Insulin } & \multicolumn{3}{|c|}{ Matched Population } & \multicolumn{3}{|c|}{ Matched Population } \\
\hline & $\begin{array}{l}4858 \\
(26.0)\end{array}$ & $\begin{array}{l}4644 \\
(24.8)\end{array}$ & 0.02 & $\begin{array}{l}4081 \\
(34.9)\end{array}$ & $\begin{array}{l}3495 \\
(29.9)\end{array}$ & 0.10 \\
\hline Other AHAs & $\begin{array}{l}18,675 \\
(99.8)\end{array}$ & $\begin{array}{l}17,938 \\
(95.8)\end{array}$ & 0.25 & $\begin{array}{l}11,610 \\
(99.4)\end{array}$ & $\begin{array}{l}11,152 \\
(95.0)\end{array}$ & 0.24 \\
\hline Metformin & $\begin{array}{l}17,879 \\
(95.5)\end{array}$ & $\begin{array}{l}14,429 \\
(77.1)\end{array}$ & 0.55 & $\begin{array}{l}10,908 \\
(93.4)\end{array}$ & $\begin{array}{l}8907 \\
(76.2)\end{array}$ & 0.49 \\
\hline Sulfonylureas & $\begin{array}{l}12,769 \\
(68.2)\end{array}$ & $\begin{array}{l}10,092 \\
(53.9)\end{array}$ & 0.29 & $\begin{array}{l}6652 \\
(56.9)\end{array}$ & $\begin{array}{l}5544 \\
(47.4)\end{array}$ & 0.19 \\
\hline Glinides & $\begin{array}{l}3002 \\
(16.0)\end{array}$ & $\begin{array}{l}1491 \\
(8.0)\end{array}$ & 0.25 & $\begin{array}{l}1433 \\
(12.3)\end{array}$ & $\begin{array}{l}745 \\
(6.4)\end{array}$ & 0.20 \\
\hline Glitazones & $\begin{array}{l}6340 \\
(33.9)\end{array}$ & $\begin{array}{l}1619 \\
(8.7)\end{array}$ & 0.64 & $\begin{array}{l}2619 \\
(22.4)\end{array}$ & $\begin{array}{l}721 \\
(6.2)\end{array}$ & 0.47 \\
\hline Acarbose & $\begin{array}{l}1656 \\
(8.8)\end{array}$ & $13(0.1)$ & 0.43 & $\begin{array}{l}1139 \\
(9.7)\end{array}$ & $\begin{array}{l}10 \\
(0.1)\end{array}$ & 0.45 \\
\hline DDP-4i & $\begin{array}{l}6430 \\
(34.4)\end{array}$ & $\begin{array}{l}184 \\
(1.0)\end{array}$ & 0.97 & $\begin{array}{l}3755 \\
(32.1)\end{array}$ & $\begin{array}{l}70 \\
(0.6)\end{array}$ & 0.94 \\
\hline $\begin{array}{l}\text { No Antihyperglycemic } \\
\text { drugs, } n(\%)\end{array}$ & $87(0.5)$ & $\begin{array}{l}823 \\
(4.4)\end{array}$ & 0.25 & $\begin{array}{l}73 \\
(0.6)\end{array}$ & $\begin{array}{l}531 \\
(4.5)\end{array}$ & 0.24 \\
\hline \multicolumn{7}{|l|}{$\begin{array}{l}\text { Medications of } \\
\text { interest, } n(\%)\end{array}$} \\
\hline $\begin{array}{l}\text { Antihypertensive } \\
\text { drugs }\end{array}$ & $\begin{array}{l}15,460 \\
(82.6)\end{array}$ & $\begin{array}{l}14,438 \\
(77.1)\end{array}$ & 0.13 & $\begin{array}{l}9669 \\
(82.7)\end{array}$ & $\begin{array}{l}9192 \\
(78.7)\end{array}$ & 0.10 \\
\hline ACE-I/ARBS & $\begin{array}{l}13,771 \\
(73.6)\end{array}$ & $\begin{array}{l}12,331 \\
(65.9)\end{array}$ & 0.16 & $\begin{array}{l}8358 \\
(71.5)\end{array}$ & $\begin{array}{l}7737 \\
(66.2)\end{array}$ & 0.11 \\
\hline Lipid lowering drugs & $\begin{array}{l}12,408 \\
(66.3)\end{array}$ & $\begin{array}{l}10,665 \\
(57.0)\end{array}$ & 0.19 & $\begin{array}{l}8113 \\
(69.4)\end{array}$ & $\begin{array}{l}7058 \\
(60.4)\end{array}$ & 0.19 \\
\hline Antiplatelet drugs & $\begin{array}{l}7460 \\
(39.9)\end{array}$ & $\begin{array}{l}7002 \\
(37.4)\end{array}$ & 0.05 & $\begin{array}{l}4412 \\
(37.7)\end{array}$ & $\begin{array}{l}3920 \\
(33.5)\end{array}$ & 0.08 \\
\hline $\begin{array}{l}\text { Oral anticoagulant } \\
\text { drugs }\end{array}$ & $\begin{array}{l}968 \\
(5.2)\end{array}$ & $\begin{array}{l}1059 \\
(5.7)\end{array}$ & -0.02 & $\begin{array}{l}723 \\
(6.2)\end{array}$ & $\begin{array}{l}956 \\
(8.2)\end{array}$ & -0.07 \\
\hline \multirow{2}{*}{$\begin{array}{l}\text { DDCI Index, median } \\
\text { [IQR] }\end{array}$} & 4 & 4 & -0.00 & 4 & 4 & 0.00 \\
\hline & {$[2,7]$} & {$[2,7]$} & & {$[2,7]$} & {$[2,7]$} & \\
\hline \multirow{2}{*}{$\begin{array}{l}\text { Hospital admission, } \\
\text { median [IQR] }\end{array}$} & 1 & 1 & -0.07 & 0 & 1 & -0.09 \\
\hline & {$[0,2]$} & {$[0,2]$} & & {$[0,2]$} & {$[0,2]$} & \\
\hline
\end{tabular}




\begin{tabular}{|c|c|c|c|c|c|c|}
\hline \multirow[b]{2}{*}{$0-4$} & \multicolumn{3}{|c|}{ Matched Population } & \multicolumn{3}{|c|}{ Matched Population } \\
\hline & $\begin{array}{l}1900 \\
(10.2)\end{array}$ & $\begin{array}{l}1843 \\
(9.8)\end{array}$ & 0.02 & $\begin{array}{l}74 \\
(0.6)\end{array}$ & $\begin{array}{l}186 \\
(1.6)\end{array}$ & 0.08 \\
\hline $5-9$ & $\begin{array}{l}6009 \\
(32.1)\end{array}$ & $\begin{array}{l}5754 \\
(30.7)\end{array}$ & & $\begin{array}{l}3097 \\
(26.5)\end{array}$ & $\begin{array}{l}3002 \\
(25.7)\end{array}$ & \\
\hline $10+$ & $\begin{array}{l}10,853 \\
(58.0)\end{array}$ & $\begin{array}{l}11.165 \\
(59.7)\end{array}$ & & $\begin{array}{l}8512 \\
(72.8)\end{array}$ & $\begin{array}{l}9495 \\
(72.7)\end{array}$ & \\
\hline
\end{tabular}


Table 1

B. Baseline characteristics of matched population according treatment status in Apulia region from 2010 to 2018

\begin{tabular}{|c|c|c|c|c|c|c|}
\hline \multirow[b]{2}{*}{ Variables } & \multicolumn{3}{|c|}{ Matched Population } & \multicolumn{3}{|c|}{ Matched Population } \\
\hline & $\begin{array}{l}\text { GLP-1 } \\
\text { RA } \\
(\mathrm{N}= \\
9,772)\end{array}$ & $\begin{array}{l}\text { Other } \\
\text { AHAs } \\
(\mathrm{N}= \\
9,772)\end{array}$ & $\begin{array}{l}\text { Standardized } \\
\text { differences }\end{array}$ & $\begin{array}{l}\text { SGLT- } \\
2 \mathbf{i} \\
(N= \\
6,046)\end{array}$ & $\begin{array}{l}\text { Other } \\
\text { AHAs } \\
(\mathrm{N}= \\
6,046)\end{array}$ & $\begin{array}{l}\text { Standardized } \\
\text { differences }\end{array}$ \\
\hline Mean age (+SD) & $\begin{array}{l}64.6 \pm \\
7.7\end{array}$ & $\begin{array}{l}64.3 \pm \\
7.9\end{array}$ & 0.03 & $\begin{array}{l}67.2 \pm \\
7.6\end{array}$ & $\begin{array}{l}67.33 \\
\pm 7.9\end{array}$ & -0.01 \\
\hline Gender (Female) & $\begin{array}{l}4892 \\
(50.1)\end{array}$ & $\begin{array}{l}4876 \\
(49.9)\end{array}$ & 0.00 & $\begin{array}{l}2714 \\
(44.9)\end{array}$ & $\begin{array}{l}2857 \\
(47.2)\end{array}$ & -0.04 \\
\hline \multicolumn{7}{|l|}{$\begin{array}{l}\text { Comorbidities of interest, } \\
\mathrm{n}(\%)\end{array}$} \\
\hline Cerebrovascular disease & $\begin{array}{l}523 \\
(5.3)\end{array}$ & $\begin{array}{l}679 \\
(6.9)\end{array}$ & -0.06 & $\begin{array}{l}409 \\
(6.8)\end{array}$ & $\begin{array}{l}430 \\
(7.1)\end{array}$ & -0.01 \\
\hline Cardiovascular disease & $\begin{array}{l}1167 \\
(11.9)\end{array}$ & $\begin{array}{l}1257 \\
(12.9)\end{array}$ & -0.02 & $\begin{array}{l}979 \\
(16.2)\end{array}$ & $\begin{array}{l}768 \\
(12.7)\end{array}$ & 0.09 \\
\hline Heart failure & $\begin{array}{l}408 \\
(4.2)\end{array}$ & $\begin{array}{l}541 \\
(5.5)\end{array}$ & -0.06 & $\begin{array}{l}290 \\
(4.8)\end{array}$ & $\begin{array}{l}371 \\
(6.1)\end{array}$ & -0.05 \\
\hline $\begin{array}{l}\text { Peripheral vascular } \\
\text { disease }\end{array}$ & $\begin{array}{l}594 \\
(6.1)\end{array}$ & $\begin{array}{l}548 \\
(5.6)\end{array}$ & 0.02 & $\begin{array}{l}320 \\
(5.3)\end{array}$ & $\begin{array}{l}323 \\
(5.3)\end{array}$ & -0.00 \\
\hline Lower limb complication & $\begin{array}{l}73 \\
(0.7)\end{array}$ & $\begin{array}{l}106 \\
(1.1)\end{array}$ & -0.03 & $\begin{array}{l}47 \\
(0.8)\end{array}$ & $\begin{array}{l}72 \\
(1.2)\end{array}$ & -0.04 \\
\hline Renal disease & $\begin{array}{l}315 \\
(3.2)\end{array}$ & $\begin{array}{l}418 \\
(4.3)\end{array}$ & -0.05 & $\begin{array}{l}154 \\
(2.5)\end{array}$ & $\begin{array}{l}328 \\
(5.4)\end{array}$ & 0.14 \\
\hline Neuropathy & $\begin{array}{l}279 \\
(2.9)\end{array}$ & $\begin{array}{l}298 \\
(3.0)\end{array}$ & -0.01 & $\begin{array}{l}141 \\
(2.3)\end{array}$ & $\begin{array}{l}129 \\
(2.1)\end{array}$ & 0.01 \\
\hline Diabetic retinopathy & $\begin{array}{l}24 \\
(0.2)\end{array}$ & $\begin{array}{l}20 \\
(0.2)\end{array}$ & 0.00 & $9(0.1)$ & $\begin{array}{l}12 \\
(0.2)\end{array}$ & -0.01 \\
\hline $\begin{array}{l}\text { Chronic obstructive } \\
\text { pulmonary disease }\end{array}$ & $\begin{array}{l}553 \\
(5.7)\end{array}$ & $\begin{array}{l}611 \\
(6.2)\end{array}$ & -0.02 & $\begin{array}{l}323 \\
(5.3)\end{array}$ & $\begin{array}{l}402 \\
(6.6)\end{array}$ & -0.05 \\
\hline Cancer & $\begin{array}{l}817 \\
(8.4)\end{array}$ & $\begin{array}{l}972 \\
(9.9)\end{array}$ & -0.05 & $\begin{array}{l}494 \\
(8.2)\end{array}$ & $\begin{array}{l}578 \\
(9.6)\end{array}$ & -0.04 \\
\hline $\begin{array}{l}\text { Antihyperglycemic drugs, } \\
\mathrm{n}(\%)\end{array}$ & & & & & & \\
\hline
\end{tabular}

Legend. GLP-1 RA: glucon-like peptide-1 receptor agonists; SGLT-2i: sodium glucose cotransporter 2 inhibitors; DPP-4i: dipeptidyl peptidase-4 inhibitors; AHAs: antihyperglycemic agents; ACE-l: angiotensin-converting enzyme inhibitors; ARBs: angiotensin II receptor agonist blockers; DCCI: Drug Derived Complexity Index; SD: standard deviation; IQR: interquartile range 


\begin{tabular}{|c|c|c|c|c|c|c|}
\hline \multirow[b]{2}{*}{ GLP-1 RA } & \multicolumn{3}{|c|}{ Matched Population } & \multicolumn{3}{|c|}{ Matched Population } \\
\hline & $0(0.0)$ & $\begin{array}{l}77 \\
(0.8)\end{array}$ & -0.12 & $\begin{array}{l}63 \\
(1.0)\end{array}$ & $\begin{array}{l}24 \\
(0.4)\end{array}$ & 0.07 \\
\hline SGLT-2i & $0(0.0)$ & $0(0.0)$ & 0.00 & $0(0.0)$ & $0(0.0)$ & 0.00 \\
\hline Insulin & $\begin{array}{l}2890 \\
(29.6)\end{array}$ & $\begin{array}{l}2628 \\
(26.9)\end{array}$ & 0.05 & $\begin{array}{l}1984 \\
(32.8)\end{array}$ & $\begin{array}{l}1876 \\
(31.0)\end{array}$ & 0.03 \\
\hline Other AHAs & $\begin{array}{l}9748 \\
(99.7)\end{array}$ & $\begin{array}{l}9338 \\
(95.6)\end{array}$ & 0.28 & $\begin{array}{l}6031 \\
(99.8)\end{array}$ & $\begin{array}{l}5817 \\
(96.2)\end{array}$ & 0.25 \\
\hline Metformin & $\begin{array}{l}9539 \\
(97.6)\end{array}$ & $\begin{array}{l}7942 \\
(81.3)\end{array}$ & 0.55 & $\begin{array}{l}5813 \\
(96.1)\end{array}$ & $\begin{array}{l}4917 \\
(81.3)\end{array}$ & 0.48 \\
\hline Sulfonylureas & $\begin{array}{l}5365 \\
(54.9)\end{array}$ & $\begin{array}{l}4289 \\
(43.9)\end{array}$ & 0.22 & $\begin{array}{l}2974 \\
(49.2)\end{array}$ & $\begin{array}{l}2259 \\
(37.4)\end{array}$ & 0.24 \\
\hline Glinides & $\begin{array}{l}3314 \\
(33.9)\end{array}$ & $\begin{array}{l}1228 \\
(12.6)\end{array}$ & 0.52 & $\begin{array}{l}1821 \\
(30.1)\end{array}$ & $\begin{array}{l}721 \\
(11.9)\end{array}$ & 0.45 \\
\hline Glitazones & $\begin{array}{l}3028 \\
(31.0)\end{array}$ & $\begin{array}{l}1027 \\
(10.5)\end{array}$ & 0.52 & $\begin{array}{l}1237 \\
(20.5)\end{array}$ & $\begin{array}{l}448 \\
(7.4)\end{array}$ & 0.38 \\
\hline Acarbose & $\begin{array}{l}811 \\
(8.3)\end{array}$ & $\begin{array}{l}17 \\
(0.2)\end{array}$ & 0.41 & $\begin{array}{l}570 \\
(9.4)\end{array}$ & $6(0.1)$ & 0.44 \\
\hline DDP-4i & $\begin{array}{l}3640 \\
(37.2)\end{array}$ & $\begin{array}{l}94 \\
(1.0)\end{array}$ & 1.04 & $\begin{array}{l}2132 \\
(35.3)\end{array}$ & $\begin{array}{l}48 \\
(0.8)\end{array}$ & 1.00 \\
\hline $\begin{array}{l}\text { No Antihyperglycemic } \\
\text { drugs, } \mathrm{n}(\%)\end{array}$ & $24(0.2$ & $\begin{array}{l}434 \\
(4.4)\end{array}$ & 0.28 & $\begin{array}{l}15 \\
(0.2)\end{array}$ & $\begin{array}{l}229 \\
(3.8)\end{array}$ & 0.25 \\
\hline \multicolumn{7}{|l|}{$\begin{array}{l}\text { Medications of interest, } \mathrm{n} \\
(\%)\end{array}$} \\
\hline Antihypertensive drugs & $\begin{array}{l}8433 \\
(86.3)\end{array}$ & $\begin{array}{l}7869 \\
(80.5)\end{array}$ & 0.15 & $\begin{array}{l}5102 \\
(84.4)\end{array}$ & $\begin{array}{l}4847 \\
(80.2)\end{array}$ & 0.11 \\
\hline ACE-I/ARBS & $\begin{array}{l}7426 \\
(76.0)\end{array}$ & $\begin{array}{l}6772 \\
(69.3)\end{array}$ & 0.15 & $\begin{array}{l}4335 \\
(71.7)\end{array}$ & $\begin{array}{l}4079 \\
(67.5)\end{array}$ & 0.09 \\
\hline Lipid lowering drugs & $\begin{array}{l}6992 \\
(71.5)\end{array}$ & $\begin{array}{l}5789 \\
(59.2)\end{array}$ & 0.26 & $\begin{array}{l}4490 \\
(74.3)\end{array}$ & $\begin{array}{l}3752 \\
(62.0)\end{array}$ & 0.26 \\
\hline Antiplatelet drugs & $\begin{array}{l}5760 \\
(58.9)\end{array}$ & $\begin{array}{l}5058 \\
(51.8)\end{array}$ & 0.14 & $\begin{array}{l}3787 \\
(62.6)\end{array}$ & $\begin{array}{l}3269 \\
(54.1)\end{array}$ & 0.17 \\
\hline Oral anticoagulant drugs & $\begin{array}{l}467 \\
(4.8)\end{array}$ & $\begin{array}{l}596 \\
(5.2)\end{array}$ & -0.01 & $\begin{array}{l}328 \\
(5.4)\end{array}$ & $\begin{array}{l}407 \\
(6.7)\end{array}$ & -0.05 \\
\hline
\end{tabular}

Legend. GLP-1 RA: glucon-like peptide-1 receptor agonists; SGLT-2i: sodium glucose cotransporter 2 inhibitors; DPP-4i: dipeptidyl peptidase-4 inhibitors; AHAs: antihyperglycemic agents; ACE-I: angiotensin-converting enzyme inhibitors; ARBs: angiotensin II receptor agonist blockers; DCCl: Drug Derived Complexity Index; SD: standard deviation; IQR: interquartile range 


\begin{tabular}{|c|c|c|c|c|c|c|}
\hline \multirow[b]{2}{*}{ DDCI Index, median [IQR] } & \multicolumn{3}{|c|}{ Matched Population } & \multicolumn{3}{|c|}{ Matched Population } \\
\hline & 5 & 5 & 0.03 & 5 & 5 & -0.00 \\
\hline & {$[3,7]$} & {$[3,7]$} & & {$[3,7]$} & {$[3,7]$} & \\
\hline \multirow{2}{*}{$\begin{array}{l}\text { Hospital admission, } \\
\text { median [IQR] }\end{array}$} & 1 & 1 & \multirow[t]{2}{*}{-0.02} & 1 & 1 & \multirow[t]{2}{*}{-0.01} \\
\hline & {$[0,2]$} & {$[0,2]$} & & {$[0,2]$} & {$[0,2]$} & \\
\hline \multicolumn{3}{|l|}{$\begin{array}{l}\text { Duration of diabetes, } n \\
(\%)\end{array}$} & \multirow[t]{4}{*}{0.02} & & & \multirow[t]{4}{*}{0.04} \\
\hline $0-4$ & $\begin{array}{l}876 \\
(9.0)\end{array}$ & $\begin{array}{l}913 \\
(9.3)\end{array}$ & & $\begin{array}{l}75 \\
(1.2)\end{array}$ & $\begin{array}{l}108 \\
(1.8)\end{array}$ & \\
\hline $5-9$ & $\begin{array}{l}3974 \\
(40.7)\end{array}$ & $\begin{array}{l}3885 \\
(39.8)\end{array}$ & & $\begin{array}{l}1489 \\
(24.6)\end{array}$ & $\begin{array}{l}1448 \\
(23.9)\end{array}$ & \\
\hline $10+$ & $\begin{array}{l}4922 \\
(50.4)\end{array}$ & $\begin{array}{l}4974 \\
(50.9)\end{array}$ & & $\begin{array}{l}4482 \\
(74.1)\end{array}$ & $\begin{array}{l}4490 \\
(74.3)\end{array}$ & \\
\hline \multicolumn{7}{|c|}{$\begin{array}{l}\text { Legend. GLP-1 RA: glucon-like peptide-1 receptor agonists; SGLT-2i: sodium glucose cotransporter } 2 \\
\text { inhibitors; DPP-4i: dipeptidyl peptidase-4 inhibitors; AHAs: antihyperglycemic agents; ACE-I: } \\
\text { angiotensin-converting enzyme inhibitors; ARBs: angiotensin II receptor agonist blockers; DCCI: Drug } \\
\text { Derived Complexity Index; SD: standard deviation; IQR: interquartile range }\end{array}$} \\
\hline
\end{tabular}


Table 2

Frequency of serious adverse events in matched population by treatment in the Lombardy and Apulia regions from 2010 to 2018

\begin{tabular}{|c|c|c|c|c|c|c|c|c|}
\hline & $\begin{array}{l}\text { Lombard } \\
\text { N (\%) }\end{array}$ & & & & $\begin{array}{l}\text { Apulia } \\
\text { N (\%) }\end{array}$ & & & \\
\hline Events & $\begin{array}{l}\text { GLP-1 } \\
\text { RA } \\
(N= \\
18,716)\end{array}$ & $\begin{array}{l}\text { Other } \\
\text { AHAs } \\
(\mathrm{N}= \\
18,716)\end{array}$ & $\begin{array}{l}\text { SGLT-2i } \\
(N= \\
11,683)\end{array}$ & $\begin{array}{l}\text { Other } \\
\text { AHAs } \\
(N= \\
11,683)\end{array}$ & $\begin{array}{l}\text { GLP1- } \\
\text { RA } \\
(\mathrm{N}= \\
9772)\end{array}$ & $\begin{array}{l}\text { Other } \\
\text { AHAs } \\
(\mathrm{N}= \\
9772)\end{array}$ & $\begin{array}{l}\text { SGLT- } \\
2 \mathrm{i} \\
(\mathrm{N}= \\
6046)\end{array}$ & $\begin{array}{l}\text { Other } \\
\text { AHAs } \\
(\mathrm{N}= \\
6046)\end{array}$ \\
\hline Hypoglycemia & $\begin{array}{l}22 \\
(0.12)\end{array}$ & $\begin{array}{l}20 \\
(0.11)\end{array}$ & $2(0.02)$ & $\begin{array}{l}11 \\
(0.09)\end{array}$ & $\begin{array}{l}8 \\
(0.08)\end{array}$ & $\begin{array}{l}10 \\
(0.10)\end{array}$ & $\begin{array}{l}1 \\
(0.02)\end{array}$ & $4(0.07)$ \\
\hline Ketoacidosis & $8(0.04)$ & $\begin{array}{l}12 \\
(0.06)\end{array}$ & $5(0.04)$ & $3(0.03)$ & $\begin{array}{l}14 \\
(0.14)\end{array}$ & $\begin{array}{l}14 \\
(0.14)\end{array}$ & $\begin{array}{l}1 \\
(0.02)\end{array}$ & $1(0.02)$ \\
\hline $\begin{array}{l}\text { Diabetic } \\
\text { coma }\end{array}$ & $6(0.03)$ & $\begin{array}{l}11 \\
(0.06)\end{array}$ & $2(0.02)$ & $3(0.03)$ & $\begin{array}{l}2 \\
(0.02)\end{array}$ & $\begin{array}{l}6 \\
(0.06)\end{array}$ & 0 & 0 \\
\hline Amputations & $\begin{array}{l}121 \\
(0.65)\end{array}$ & $\begin{array}{l}208 \\
(1.11)\end{array}$ & $\begin{array}{l}54 \\
(0.46)\end{array}$ & $\begin{array}{l}63 \\
(0.54)\end{array}$ & $\begin{array}{l}44 \\
(0.45)\end{array}$ & $\begin{array}{l}69 \\
(0.71)\end{array}$ & $\begin{array}{l}15 \\
(0.25)\end{array}$ & $\begin{array}{l}24 \\
(0.40)\end{array}$ \\
\hline $\begin{array}{l}\text { Acute renal } \\
\text { failure }\end{array}$ & $\begin{array}{l}17 \\
(0.09)\end{array}$ & $\begin{array}{l}10 \\
(0.05)\end{array}$ & $2(0.02)$ & $2(0.02)$ & $\begin{array}{l}14 \\
(0.14)\end{array}$ & $\begin{array}{l}16 \\
(0.16)\end{array}$ & $\begin{array}{l}4 \\
(0.07)\end{array}$ & $6(0.10)$ \\
\hline Syncope & $\begin{array}{l}91 \\
(0.49)\end{array}$ & $\begin{array}{l}99 \\
(0.53)\end{array}$ & $\begin{array}{l}27 \\
(0.23)\end{array}$ & $\begin{array}{l}29 \\
(0.25)\end{array}$ & $\begin{array}{l}28 \\
(0.29)\end{array}$ & $\begin{array}{l}57 \\
(0.58)\end{array}$ & $\begin{array}{l}6 \\
(0.10)\end{array}$ & $\begin{array}{l}17 \\
(0.28)\end{array}$ \\
\hline Fractures & $\begin{array}{l}462 \\
(2.47)\end{array}$ & $\begin{array}{l}517 \\
(2.76)\end{array}$ & $\begin{array}{l}150 \\
(1.28)\end{array}$ & $\begin{array}{l}176 \\
(1.51)\end{array}$ & $\begin{array}{l}224 \\
(2.29)\end{array}$ & $\begin{array}{l}249 \\
(2.55)\end{array}$ & $\begin{array}{l}44 \\
(0.73)\end{array}$ & $\begin{array}{l}78 \\
(1.29)\end{array}$ \\
\hline
\end{tabular}

Figures

1A

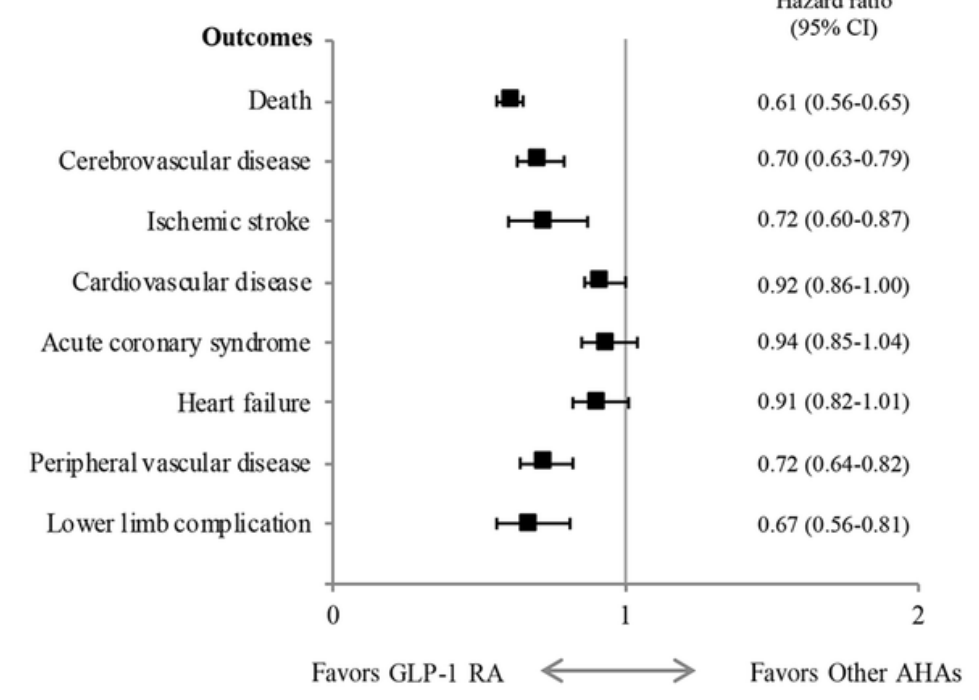

1B

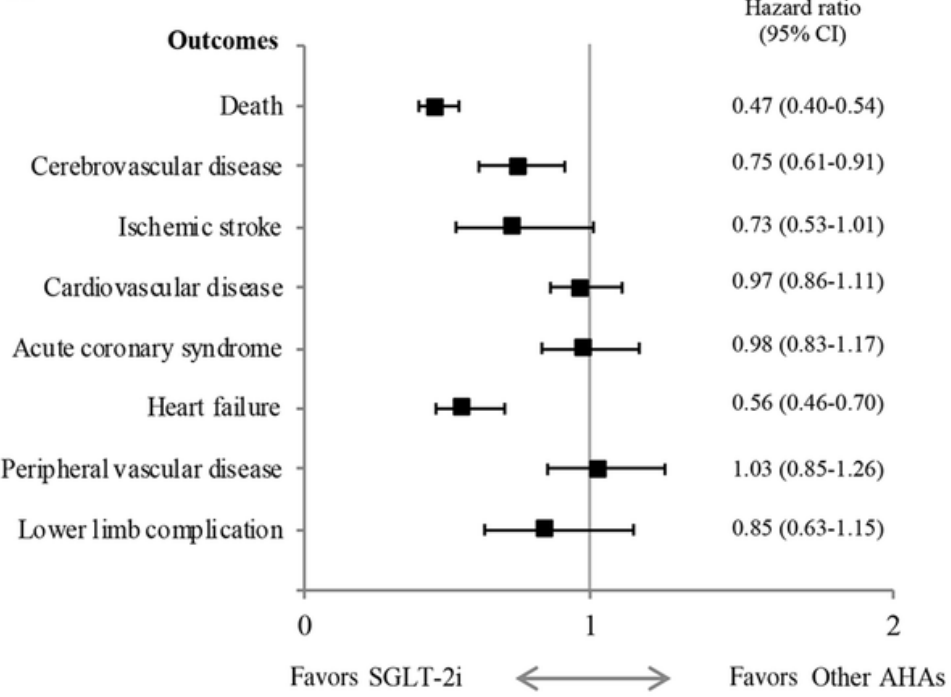


Figure 1

Hazard ratios $(95 \%, \mathrm{Cl})$ for death and clinical events in matched populations according to treatment status in the Lombardy region. Legend: GLP-1 RA; glucagon-like peptide-1 receptor agonists; SGLT-2i: glucose cotransporter-2 inhibitors; AHAs: anti-hyperglycemic agents

2A

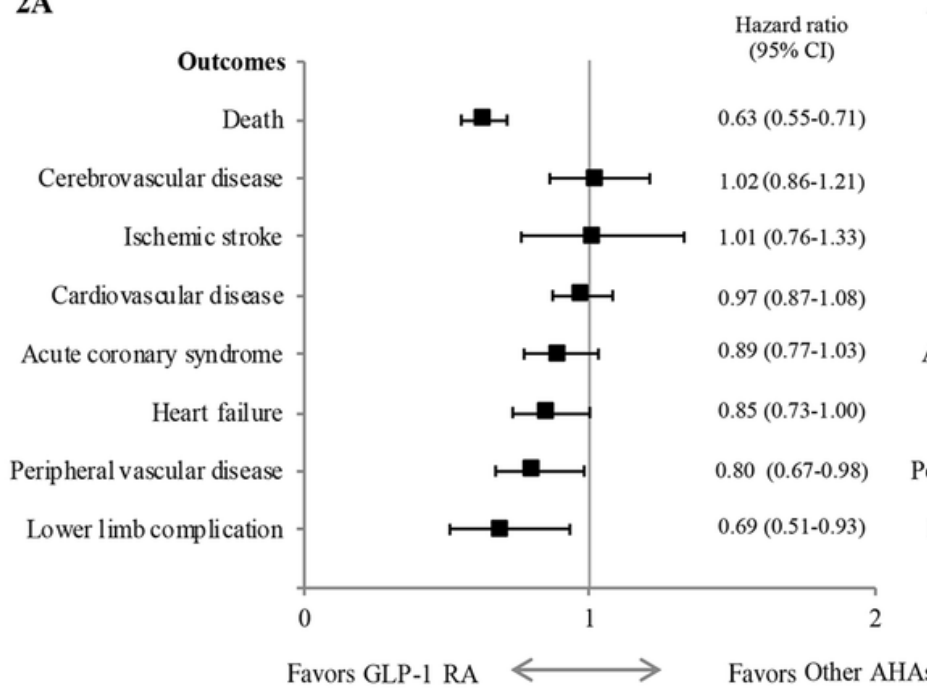

2B

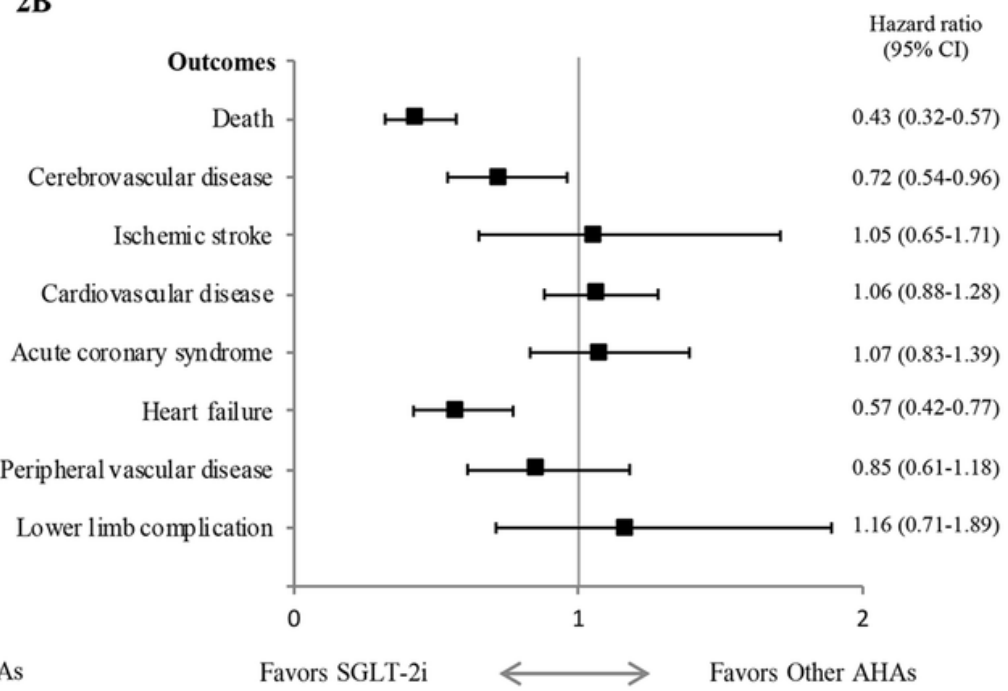

\section{Figure 2}

Hazard ratios $(95 \%, \mathrm{Cl})$ for death and clinical events in matched populations according to treatment status in the Apulia region. Legend: GLP-1 RA; glucagon-like peptide-1 receptor agonists; SGLT-2i: glucose cotransporter-2 inhibitors; AHAs: anti-hyperglycemic agents

\section{Supplementary Files}

This is a list of supplementary files associated with this preprint. Click to download.

- Supplementarymaterial.pdf 